\title{
New Requirements for Recertification in the Year 2001
}

$\mathrm{D}$ iplomates of the American Board of Thoracic Surgery who plan to participate in the recertification process within the next few years should pay particular attention to this notice, since the requirements will change effective in the year 2001 .

In addition to an active medical license and institutional clinical privileges in thoracic surgery, beginning in 2001, a valid certificate will be an absolute requirement for entrance into the recertification process. If your certificate has expired, the only pathway for renewal of a certificate will be to take and pass the Part I (written) and the Part II (oral) certifying examinations.

In 2001, the American Board of Thoracic Surgery will no longer publish the names of individuals who have not recertified. In the past, a designation of "NR" (not recertified) was used in the American Board of Medical Specialties directories if a Diplomate had not recertified. The Diplomate's name will be published upon successful completion of the recertification process.

The CME requirements will also change in 2001. The new CME requirements will be 70 Category I credits in either cardiothoracic surgery or general surgery earned during the 2 years prior to applying for recertification. SESATS and SESAPS will be the only self-instructional material allowed for credit. No Category II credits will be allowed. The Physicians Recognition Award for recertifying in general surgery will not be accepted in fulfillment of the CME requirement for recertification. The preceding information only partially outlines the $\mathrm{CME}$ requirements. Interested individuals should refer to the 1999 Booklet of Information for a complete description of acceptable CME credits.

Diplomates should maintain a documented list of their major cases performed during the year prior to application for recertification. This practice review should consist of 1 year's consecutive major operative experiences. If more than 100 cases occur in 1 year, only 100 should be listed.

Candidates for recertification will be required to complete both the general thoracic and the cardiac portions of the SESATS self-assessment examination. It is not necessary for candidates to purchase SESATS prior to applying for recertification since SESATS will be sent to candidates after their application has been approved.

Diplomates may recertify up to 3 years before the expiration of their certificate. Their new certificate will be dated 10 years from the time of expiration of their original certificate or most recent recertification certificate. In other words, recertifying early does not alter the 10 -year validation.

Recertification is also open to Diplomates with an unlimited certificate and will in no way affect the validity of their original certificate.

The deadline for submission of applications for the recertification process is May 1 each year. A recertification brochure outlining the rules and requirements for recertification in thoracic surgery is available upon request from the American Board of Thoracic Surgery, One Rotary Center, Suite 803, Evanston, Illinois 60201 (telephone: 847-475-1520; fax: 847-475-6240; e-mail: abts_evanston@msn.com).

\section{THE THORACIC SURGERY FOUNDATION FOR RESEARCH AND EDUCATION}

\section{Kennedy School Sabbatical}

$\mathrm{T}$ he Thoracic Surgery Foundation for Research and Education announces that applications for a yearlong sabbatical to do graduate studies in health care policy at Harvard University's Kennedy School of Government are now available. Candidates will be accepted early on a rolling admission basis by the graduate school, and scholarships will be awarded by The Foundation's Education Committee. The Kennedy School will review completed applications for the program starting January 1, 1999, and is pre- 